\author{
O. Serdiuk, \\ PhD (Economics), \\ ORCID 0000-0003-3049-3144, \\ e-mail: oleksandrserdyk@ukr.net,
}

\section{Petrova,}

PhD (Economics),

ORCID 0000-0002-0515-5349,

e-mail: msirynapetrova@gmail.com,

Institute of Industrial Economics of NAS of Ukraine, Kyiv

\title{
GENERALIZATION OF TOOLS FOR INTERNALIZATION OF NEGATIVE EXTERNALITIES IN THE EUROPEAN UNION: CONCLUSIONS FOR UKRAINE
}

Ukrainian industry produces a large number of potential pathogens of negative externalities, the total volume of which exceeds that of other sectors of the economy. This situation is due to the specifics of old industrial production models, whose share in the structure of Ukrainian industry reaches $95 \%$. A fundamental feature of old-fashioned production models is the highvolume processing of raw materials using fossil fuel energy. The process of processing and production of energy is accompanied by the production of large amounts of waste in the form of solid and gaseous substances. Waste is the main, potential causative agent of negative externalities. The negative impact of waste from old industrial production models on the environment is the quintessence of negative externalities (externalities) in the economy.

As industrial production in Ukraine produces a significant part of waste, the issues of detection and internalization of negative externalities are extremely important. The main problem is that in the context of internalization of negative externalities of industrial production it is difficult to establish the presence of artificial pollution (not of natural origin) and assess its impact on economic processes. In addition, the country lacks the institutional conditions for internalizing negative externalities and has not developed an appropriate institutional environment.

Analysis of the current state of research on the processes of internalization of negative externalities allows us to conclude [1-6] that in general for Ukraine remains unresolved a number of issues of theoretical and applied nature. In particular, there is a need to generalize the tools of internalization of negative externalities in the European Union and assess the feasibility of these tools in Ukraine

In this regard, the purpose of the article is to summarize the tools of internalization of negative externalities in the European Union and assess the feasibility of these tools in Ukraine.

\section{European experience of internalization of negative externalities}

Today in European practice there are three main approaches to the internalization of negative externali- ties: direct regulation, the use of market (economic) instruments and institutional. The first approach involves direct regulation through rules, prohibitions, restrictions to correct the behavior of the source of external effects.

Direct regulation determines permissible behavior and establishes penalties for violating the rules of conduct. Covers a wide range of direct action management tools established by law. The legislation formulates its objectives to achieve a certain quality of the environment in technical and production norms / standards, standards and requirements that are designed to restrict the freedom of choice of the economic entity. A necessary condition for the effective application of direct regulation methods is strict control over compliance with the law and the establishment of fairly strict measures of responsibility for their violation.

The most common tool is norms (standards). There are two types of standards:

- environmental quality standards (ambient standards);

- emission standards.

Environmental quality standards characterize the quality of the environment (emission limit values $(\mathrm{ELV})$ ). In the European Union (EU), air quality is regulated by setting quality standards - limit values / targets. They are based on special principles that apply to all issues governed by EU environmental law:

the principle of taking into account the impacts the specific impact on the recipients (person / object of the environment) is assessed, while not considering the technological feasibility of quality standards or the economic feasibility of ensuring compliance with them;

the principle of universality is realized in the definition of uniform standards;

the principle of practical reachability has led to the emergence of the concept of intervals of acceptable deviations (Margins of Tolerance), formed on the basis of the difficulty of achieving the requirements of the standards;

the principle of uncertainty of requirements for any specific technologies motivates the search for innovative solutions, as standards tend to increase, and over time, more stringent standards are adopted; 
the principle of best available technologies provides for the practical implementation of relevant technological and technical solutions to prevent / reduce emissions of harmful substances and the possibility of application in a particular region;

The "polluter pays" principle is currently key in EU environmental policy and provides that the costs of preventing / reducing pollution and measures aimed at restoring the environment are responsible for pollution (economic operators).

And, in turn, regulations set restrictions on the entry of pollutants into the environment from various sources. Emission standards are divided into two types:

quantitative limits on the amount or concentration of emissions (performance standards);

technological standards for equipment or technological processes (technology standards).

For example, in the United Kingdom, air quality is regulated in accordance with The Airquality Strategy (2007) by setting clear deadlines for quality targets (concentration is reached by a certain date; after the deadline, exceedances are prohibited). The list of priority substances, along with ozone, carbon monoxide, nitrogen and sulfur dioxins, suspended solids and lead, includes benzene, 1,3-butadiene and polycyclic aromatic hydrocarbons. Similar to the provisions of EU legislation, air quality targets have been set for the protection of plants and ecosystems, as the object of protection, in addition to human life and health, can be objects of nature [7].

The United States has introduced a system of primary (installed and enforced for health, including sensitive groups) and secondary (installed to protect property, including reduced visibility, harm to animals, crops, plants and buildings) air quality standards, 1990). For each substance, the specified number of exceedances of the specified quality standards, for example, the primary standards of carbon monoxide can not be exceeded more than once a year.

Australia has air quality standards, the specificity of which is to determine the averaging period and the maximum number of cases per year (WHO 2000). Indicator air pollutants include carbon monoxide, lead, ozone, nitrogen dioxide, sulfur dioxide and suspended solids.

An example of technological regulation is the standards of best available technologies, widely used in European countries since the mid-90s, in accordance with the Council of Europe Directive 96/61 / EC on integrated pollution control and prevention [8]. The main purpose of the introduction of the best available technologies is to improve the management and control systems of production processes in industrial enterprises to ensure an integrated approach to environmental protection. The use of the best available technologies allows to increase technological efficiency and environmental safety at industrial facilities. Guiding documents on technological rationing are constantly modified in accordance with the advanced and most effective today production processes and equipment. In the EU, they are used in the process of issuing permits to industrial enterprises for wastewater discharge, emissions into the atmosphere and disposal of solid waste. The best available techniques allow to assess the practical suitability of specific technologies to ensure compliance with environmental standards developed and used to prevent and / or reduce discharges, emissions and overall environmental impact.

Therefore, evaluating the tools of direct regulation, we can state that they are:

- do not minimize environmental costs;

- do not stimulate the reduction of pollution above the level established by norms (standards);

- have high costs of administration and control. However, these methods allow (with effective control) guaranteed to achieve the target quality standards of the environment for a fixed period of time. The latter property is especially important in the initial stages of environmental policy, when it is important to quickly normalize the environmental situation.

The second approach uses economic (market) regulatory instruments, where the main way of influencing market instruments is the correction of pricing and resource allocation [9]. In European practice, such instruments as trading permits (market instrument) and emission charges (Pig tax) are widely used.

In the European Union, an example of permit trading is the emissions trading system [10], which was introduced in the EU in 2005. The EU Emissions Trading System (EU ETS) is the main instrument for the EU to achieve its goals of reducing greenhouse gas emissions, which are declared internationally and reflected in EU legislation. The EU ETS operates on the principle of limiting greenhouse gas emissions and trading in greenhouse gas emissions permits. Proceeds from the sale of greenhouse gas emissions permits provide Member States with revenue that can be used, inter alia, for programs to reduce carbon and renew renewable energy. On the one hand, the price of emissions increases the costs associated with activities that cause pollution. On the other hand, the EU ETS encourages emission reductions in those enterprises where it is most financially advantageous.

The EU ETS operates in 31 countries (all $28 \mathrm{EU}$ countries, as well as Iceland, Liechtenstein and Norway) and limits emissions from more than 11,000 power plants (power plants and industrial enterprises) and airlines operating between these countries. Thus, the EU ETS covers about $45 \%$ of greenhouse gas emissions in the EU. The EU ETS also promotes emissions trading in other countries and regions [11].

The system of permit trading on the example of emissions trading has its own features, which are [9]:

guaranteed compliance with the established restrictions on access to the resource and allows you to determine the market price of this access;

allows polluters to be flexible, and to choose between installing treatment equipment and purchasing permits; 
stimulates technical progress, as excess permits can be sold, which in itself ensures the transfer of emission rights to those who value them above. However, the transaction costs of implementing this approach can be extremely high.

Central among economic (market) instruments is the fee / emission tax (emission tax), or Piguvian tax, the effectiveness of which has been studied in detail in theory and has already gained practical experience.

A. Pigou showed that the efficient allocation of resources can be ensured by setting commodity prices at the level of marginal social costs. The real price of a good must be adjusted by a tax equal to the difference between the public and private marginal costs at the point of efficient production. Determining the amount of tax and developing a mechanism for its implementation is entrusted to the state [12].

Full internalization of negative externalities through the Pig tax is possible if the controlling body has the information:

about the magnitude of the negative external effects of pollution;

marginal cost functions of individual emission sources.

Since this is practically impossible, in the scientific literature the Pig tax is considered as a theoretical construction rather than as a specific tool. If the tax is underestimated, it is impossible to achieve the goal - internalization of negative externalities and, accordingly, efficient allocation of resources, and if it is overestimated - additional burden is imposed on producers / consumers.

There is no single unified system of such taxes in Europe [13]. The tax base is a physical unit that has a specific, proven negative impact on the environment. It should be noted that environmental taxes in the EU include the following groups of payments [14]:

energy taxes - taxes on energy products, including coal, petroleum products, gas, electricity, fuel, etc.; transport taxes - payments for the import, operation, disposal of vehicles, their sales and resales;

taxes on environmental pollution - payments for direct emissions of pollutants into the air, discharges into water bodies, noise pollution;

taxes for the use of natural resources - for the extraction of minerals, water intake, etc.

It should be noted that the new European strategy for economic development "Europe 2020: a strategy for smart, sustainable and comprehensive growth" pays considerable attention to implementing the idea of more rational use of natural resources, improving the environmental situation, developing new environmentally friendly technologies. According to the single environmental strategy, which is designed for 2020 and is called the "Strategy 20-20-20", it is planned to reduce greenhouse gas emissions by $20 \%$ (from the level of 1990), to increase the share of energy production to $20 \%$ through renewable energy sources, and the total energy consumption of EU member states should be reduced by
$20 \%$ [15]. In the EU member states, energy taxes (Austria, Great Britain, Italy, the Netherlands, Slovenia, Sweden) are common environmental taxes. These are taxes on the consumption of electricity, coal, natural gas and fuel; mineral fuel tax (Austria, Great Britain, Greece, Denmark, Ireland, Spain, Italy, Luxembourg, Netherlands, Germany, Slovakia, France) [16, p. 11].

In practice, emissions taxes are set in one of two ways [9]: 1) by an iterative trial and error procedure - a consistent increase or decrease in the tax (depending on how the initial level was set) or 2) by establishing certain environmental standards, to achieve which the fee / tax is used as an aid. The real system of emissions payments is a kind of payments based on estimates of the quantity and quality of pollution, which allow to create incentives for the polluter to reduce pollution and to some extent replenish the budget / trust funds (double dividend). In this sense, taxes are perceived as a basic principle of modern environmental policy in developed countries. However, according to Western economists, real taxes everywhere are set below effective.

Pig taxes allow companies to be flexible (choose to pay or reduce emissions). Correctly, set taxes stimulate technological development (introduction of naturesaving technological processes) and minimize environmental costs of society. However, the calculation of the tax requires a significant amount of information, which the controlling body usually does not have.

Due to the predominantly fiscal orientation of economic instruments and insufficient efficiency of the system of control over the reliability of reporting data of entrepreneurs, they are not interested in allocating funds to funds or in the implementation of environmental measures. There is a need to adjust the existing system for more efficient use of business entities and reduce the cost of ensuring its operation.

Thus, the permit trading system has the following features. First, it is guaranteed to ensure compliance with the established restrictions on access to the resource and allows you to determine the market price of this access. Second, it allows businesses to be flexible by choosing between installing treatment equipment and purchasing permits. Third, it encourages technical progress, as surplus permits can be sold and allow emissions rights to be passed on to those who value them more. However, transaction costs must be taken into account, which can be extremely high.

It should be recognized that the economic nature of the Pigou tax and the permit trading system is the same the tax should be considered as a form of monetary realization of property rights, and the introduction of pollution charges simply suggests that the polluter is not the sole owner of assimilation potential. (by the state). The difference between a permit and a tax is that the "value" of a permit is set by the market and it is more tax-free than the opportunistic behavior of the bureaucracy. Another difference is that the emissions trading system does not require a large amount of information unlike the tax system. 


\section{Research of institutional tools of internalization of negative external effects}

Historically, the first in the internalization of negative externalities began to develop tools for direct regulation. Then economic (market) instruments became widely used. However, neither the first nor the second could not completely solve the problem of internalization of negative externalities. The third stage in the development of tools for internalizing negative externalities was the introduction of institutional regulatory tools, which include disclosure strategies and voluntary business initiatives.

As part of the disclosure strategy, information is seen as a public good. In certain situations, there is an "asymmetry of information", which interferes with the effective functioning of the market. It is clear that the polluter is not interested in disseminating information about its activities. On the other hand, the benefits of "informed pollutant behavior" for the individual consumer create less information acquisition costs. In addition, the disclosure strategy provides for the conditions under which companies must disclose information about the source of negative externalities. This tool aims to make it profitable for companies to demonstrate high environmental performance.

Under the Environmental and Public Information Act 1986, the United States implemented a program to inventory toxic emissions that had not been previously controlled. All companies that used more than $£ 10,000$ of chemicals or imported, processed or produced more than $£ 25,000$ of chemicals on a list had to report annually to state and municipal authorities. These reports were available to the general public. According to the EPA, as a result of this program, emissions have been reduced by $44 \%$, and the cost of many chemical companies has decreased significantly [17].

Within the framework of the instrument of voluntary business initiatives, environmental certification, environmental labeling, environmental reporting, selfregulation in the form of setting their own environmental goals, developing their own environmental policy, codes of conduct, etc.

The most common forms of environmental certification are the international standards of environmental management, which contain requirements for planning, management and control of environmental activities carried out by enterprises in order to achieve consistent improvement of environmental performance in accordance with environmental policy.

An example of voluntary business initiatives is the EMAS (Eco-Management and Audit System) - a voluntary certification program for European industrial enterprises, which aims to assess the environmental performance of industrial enterprises and create conditions for providing the public with full environmental information. In the EMAS system, the main emphasis is on in-house methods of environmental protection.

Another voluntary initiative is eco-labeling, which informs customers about the environmental properties of products and is actively used in advertising. Certification systems for obtaining eco-labels include a set of requirements, the main of which are: a) the presence of a quality end product that does not contain substances that adversely affect the human body; b) minimal negative impact on the environment at all stages of the product life cycle; c) recycling / recycling of waste and packaging. Compliance with these requirements means, in essence, that the company largely internalizes the negative externalities [9].

Therefore, for companies to publicly demonstrate the development of their own policies in the field of environmental protection, appropriate codes of conduct, the publication of environmental reports to society is considered the norm. However, there is very little evidence of the effectiveness of these initiatives. Moreover, there is no legal liability for non-fulfillment of the obligation. At the same time, the only "justice" is a broad public condemnation of the company's actions for non-compliance with the declared actions.

As follows from the above analysis, there is no universal tool that would provide full internalization of negative externalities. In other words, no internalization tool can be considered the best in all situations, so for any field of activity it is necessary to take into account a large number of factors and regional characteristics.

The use of tools for internalization of negative externalities for old industrial production models has its own specifics. The fact is that the problem of internalization is complicated by the general economic crisis and the decisive role in this process belongs to the state (direct regulatory instruments), because economic (market) and institutional instruments can not work due to underdeveloped institutional structure of the economy. There is no ready-made functioning model of internalization anywhere in the world. Therefore, in modern conditions, the most successful solution will be the development and improvement of tools for direct state regulation of negative externalities in combination with economic (market) instruments, because both economic and market instruments can work effectively and purposefully only if environmental quality standards are established and observed. environment.

For example, as a result of direct tools for internalization of negative externalities (minimization of waste by its utilization, treatment of industrial emissions, etc.), metallurgical enterprises export slag waste generated in the process of metal remelting. For a long time in the structure of these wastes, chemical processes occur, accompanied by the release into the atmosphere of a number of chemicals. At the same time, there is no exact assessment of the negative consequences of the further stay of waste in the natural environment.

This example shows that only the use of direct control tools is clearly insufficient, and to consider them as the only tool for internalization is ineffective because it gives only a short-term effect - slag dumps concentrate pollutants, and these concentrations themselves gradually become secondary sources of technogenesis. 
And if the state influence on metallurgical enterprises through direct instruments is combined with the use of stimulating economic (market) instruments, it is possible to further use metallurgical slag to obtain additional metal, which can not be removed by traditional processing, but can be obtained using modern technologies and equipment by the enterprise or the enterprise interested in use of the given waste as initial raw materials.

This combination, based on direct government intervention and the use of stimulating market instruments (technological and organizational innovations), marks the beginning of a radical structural transformation of the economic system, as it allows cooperation between enterprises and the state, NGOs, the public and other stakeholders. on the other hand.

To do this, among the direct tools of internalization of external effects, it is advisable to apply quality standards, licensing, direct control of certain economic activities, development and implementation of best available technologies, transfer of certain functions that contribute to greening production, other outsourced organizations. Economic (market) instruments are undoubtedly more flexible and focused on ensuring maximum efficiency of social production and rational use of the assimilation potential of the ecosystem.

\section{Literature}

1. Wendner R. Consumption Externalities and Pigouvian Ranking - A Generalized CobbDouglas Example. MPRA Paper No. 8540/.2008. URL: https://mpra.ub. uni-muenchen.de/8540/1/MPRA paper 8540.pdf.

2. Demsetz H. The core disagreement between Pigou, the profession, and Coase in the analyses of the externality question. European Journal of Political Economy. 1996. Vol. 12. Pp. 565-579. URL: https://pdfs.semanticscholar. org/85f8/8907224583be185bf10a8061ab8db47e75e3.pdf. 3. Berta N., Bertrand E. Market internalization of externalities: What is failing? Journal of History of Economic Thought. 2014. Vol. 36 (3). P. 332-357. 4. Medema S. G. The curious treatment of the Coase theorem in the environmental economics literature, 1960-1979. Review of Environmental Economics and Policy. 2014. Volume 8, Number 1. Р. 39-57. 5. Харічков С., Мартіснко А. Методологічні основи інституціональної теорії у формуванні концепції власності на природні ресурси. Економічна теорія. 2006. № 2. С. 65-73. 6. Гаркушенко О. М. Особливості екологічного регулювання економіки в країнах BRICS та CAEC: загрози та можливості для України. Економіка промисловості. 2016. №1 (73). С. 53-72. 7. У чому розбіжності між європейським та українським підходами до нормування якості повітря? URL: https:/ecolog-ua.com/news/uchomu-rozbizhnosti-mizh-yevropeyskym-ta-ukrayinskym -pidhodamy-do-normuvannya-yakosti-povitrya. 8. Найкращі доступні технології. Екозахист. URL: https: //ecozahist.com.ua/tekhnologiyi/. 9. Ховавко И. Ю. Инструменты интернализации внешних экологических эффектов. Вестник Марийского государственного технического университета. Серия: экономика и управление. 2011. №3 (13). С. 15-24. 10. Свропейська система торгівлі викидами та перспективи впровадження системи торгівлі викидами в Україні. Експертно-дорадчий центр «Правова аналітика». URL: https://www.rac.org.ua/uploads/content/449/files/webetsi nukraine2018ualayout.pdf. 11. Sebastian Oberthür \& Claire Roche Kelly. (2008). EU Leadership in International Climate Policy: Achievements and Challenges, The International Spectator, 43:3, 35-50. doi: 10.1080/ 03932720802280594. 12. Пигу А. С. Экономическая теория благосостояния. Москва: Прогресс, 1985. Т. 1. 13. Сучек С. Екологічне оподаткування: європейський досвід та перспективи його застосування в українських реаліях. Економічний часопис Східноєвропейського національного університету імені Лесі Українки. 2018. №3. C. 85-93. doi: https://doi.org/10.29038/2411-40142018-03-85-93. 14. Яцішин Є. Екологічне оподаткування: українські реалії та європейська практика. Юридична газета онлайн. 2018. URL: https://yur-gazeta.com/ publications/practice/ekologichne-pravo-turistichne-pravo /ekologichne-opodatkuvannya-ukrayinski-realiyi-ta-evro peyska-praktika.html. 15. Europe 2020: A strategy for smart, sustainable and inclusive growth. Communication from the Commission. European Commission. Brussels, 2010, 03 March. 32 p. 16. Green policies in the EU: A review, EC-IILS joint discussion paper series. № 14.57 p. The Political Economy of Environmentally Related Taxes, 2006. 19 June. Paris: OECD. P. 10. URL: http: //www.ec.europa.eu/social/BlobServlet?docId=7246\&langId=en. 17. Tietenberg T. H. Disclosure Strategies for Pollution Control. Environmental and Resource Economics. URL: http://www.bren.ucsb.edu/academics/courses/ 296-1W/Readings\%20-\%20Class\%204/Tietenberg\%20E RE.pdf.

\section{References}

1. Wendner, R. (2008). Consumption Externalities and Pigouvian Ranking - A Generalized CobbDouglas Example. MPRA Paper, No. 8540. Retrieved from https: //mpra.ub.uni-muenchen.de/8540/1/MPRA_paper_8540. pdf.

2. Demsetz, H. (1996). The core disagreement between Pigou, the profession, and Coase in the analyses of the externality question. European Journal of Political Economy, Vol. 12, pp. 565-579. Retrieved from https: //pdfs.semanticscholar.org/85f8/8907224583be185bf10a8 061ab8db47e75e3.pdf.

3. Berta, N., Bertrand, E. (2014). Market internalization of externalities: What is failing? Journal of History of Economic Thought, Vol. 36 (3), pp. 332-357.

4. Medema, S. G. (2014). The curious treatment of the Coase theorem in the environmental economics literature, 1960-1979. Review of Environmental Economics and Policy, Vol. 8, No. 1, pp. 39-57.

5. Kharichkov, S., Martiienko, A. (2006). Metodolohichni osnovy instytutsionalnoi teorii $\mathrm{u}$ formuvanni kontseptsii vlasnosti na pryrodni resursy [Methodological bases of institutional theory in the formation of the concept of ownership of natural resources]. Ekonomichna teoriiaEconomic theory, 2, pp. 65-73 [in Ukrainian].

6. Garkushenko O. M. (2016). Peculiarities of environmental regulation of economy in countries of BRICS 
and EEU: threats and opportunities for Ukraine. Econ. promisl., 1 (73), pp. 53-72. doi: https://doi.org/10.15407/ econindustry2016.01.062 [in Ukrainian].

7. U chomu rozbizhnosti mizh yevropeiskym ta ukrainskym pidkhodamy do normuvannia yakosti povitria? [What are the differences between European and Ukrainian approaches to air quality regulation?]. (n.d.). Retrieved from https:/ecolog-ua.com/news/u-chomu-rozbizhnostimizh-yevropeyskym-ta-ukrayinskym-pidhodamy-do-nor muvannya-yakosti-povitrya [in Ukrainian].

8. Naikrashchi dostupni tekhnolohii [The best available technology]. Ekozakhyst-Eco-protection. (n.d.). Retrieved from https://ecozahist.com.ua/tekhnologiyi/ [in Ukrainian]

9. Khovavko I. Yu. (2011). Tools for the internalization of external environmental effects. Bulletin of the Mari State Technical University. Series: Economics and Management, 3 (13), pp. 15-24 [in Russian].

10. Yevropeiska systema torhivli vykydamy ta perspektyvy vprovadzhennia systemy torhivli vykydamy $\mathrm{v}$ Ukraini [European emissions trading system and prospects for implementation of the emissions trading system in Ukraine]. Expert and Advisory Center "Legal Analytics". (n.d.). Retrieved from https://www.rac.org.ua/uploads/ content/449/files/webetsinukraine2018ualayout.pdf [in Ukrainian]

11. Sebastian Oberthür \& Claire Roche Kelly. (2008). EU Leadership in International Climate Policy: Achievements and Challenges, The International Spectator, 43:3, pp. 35-50. doi: 10.1080/03932720802280594.

12. Pigou, A. S. (1985). Economic theory of welfare. Vol. 1. Moscow, Progress [in Russian].

13. Suchek, S. (2018). Ekolohichne opodatkuvannia: yevropeiskyi dosvid ta perspektyvy yoho zastosuvannia $\mathrm{v}$ ukrainskykh realiiakh [Environmental taxation: European experience and prospects for its application in Ukrainian realities]. Ekonomichnyi chasopys Skhidnoievropeiskoho natsionalnoho universytetu imeni Lesi Ukrainky - Economic Journal of the Lesia Ukrainka East European National University, 3, pp. 85-93. doi: https://doi.org/10.29038/ 2411-4014-2018-03-85-93 [in Ukrainian].

14. Yatsishyn, Ye. (2018). Ekolohichne opodatkuvannia: ukrainski realii ta yevropeiska praktyka [Ecological taxation: Ukrainian realities and European practice.]. Yurydychna hazeta onlain - Legal newspaper online, 23 (625). Retrieved from https://yur-gazeta.com/publications/practice/ekologichne-pravo-turistichne-pravo/ekolo gichne-opodatkuvannya-ukrayinski-realiyi-ta-evropeyskapraktika.html [in Ukrainian].

15. Europe 2020: A strategy for smart, sustainable and inclusive growth. Communication from the Commission. European Commission. Brussels, 2010, 03 March. $32 \mathrm{p}$.

16. Green policies in the EU: A review, EC-IILS joint discussion paper series. № 14. 57 p. The Political Economy of Environmentally Related Taxes, 2006. 19 June. Paris: OECD. P. 10. Retrieved from http://www.ec.europa.eu/social/BlobServlet?docId=7246\&langId=en.

17. Tietenberg, T. H. Disclosure Strategies for Pollution Control. Environmental and Resource Economics. Retrieved from http://www.bren.ucsb.edu/academics/ courses/296-1W/Readings\%20-\%20Class\%204/Tietenberg\%20ERE.pdf.
Сердюк О. С., Петрова І. П. Узагальнення інструментів для інтерналізації негативних зовнішніх ефектів у Свропейському Союзі: висновки для України

Проведено порівняльний аналіз інструментів інтерналізації негативних зовнішніх ефектів. На основі узагальнення та оцінки можливостей використання інструментів інтерналізації негативних зовнішніх ефектів визначено області застосування, а також сильні і слабкі сторони прямого регулювання, економічних (ринкових) та інституційних інструментів. Охарактеризовано інструменти прямого регулювання, та виявлено, що вони не забезпечують мінімізацію економічних витрат та відрізняються високими витратами адміністративного характеру. Проаналізовано економічні (ринкові) інструменти регулювання та виявлено, що в європейській практиці широко застосовуються такі інструменти як торгівля дозволами (ринковий інструмент) та плата за викиди (податок Пігу). Розглянуто та проаналізовано інституційні інструменти регулювання як стратегія розкриття інформації та добровільні ініціативи. Обгрунтовано, що не існує універсального інструменту, який забезпечував би повну інтерналізацію негативних зовнішніх ефектів. Виявлено, що в сучасних умовах, найбільш вдалим рішенням буде розвиток і вдосконалення інструментів прямого державного регулювання негативних зовнішніх ефектів у поєднані 3 економічними (ринковими) інструментами, адже і економічні, і ринкові інструменти можуть ефективно і цілеспрямовано працювати тільки за умови встановлення і дотримання екологічних стандартів якості навколишнього середовища. Надано характеристику застосування інструментів інтерналізації негативних зовнішніх ефектів на прикладі шлакових відвалів.

Ключові слова: інтерналізація негативних зовнішніх ефектів, інструменти, Європейський Союз, зарубіжний досвід, прямі інструменти регулювання, економічні (ринкові) інструменти регулювання, інструменти інституційного регулювання, старопромислові моделі виробництва.

Serdiuk O., Petrova I. Generalization of Tools for Internalization of Negative Externalities in the European Union: Conclusions for Ukraine

A comparative analysis of the tools of internalization of negative external. Based on the generalization and assessment of the possibilities of using the tools of internalization of negative externalities, the areas of application, as well as the strengths and weaknesses of direct regulation, economic (market) and institutional tools are identified. The tools of direct regulation are characterized, and it is found that they do not minimize economic costs and have high administrative costs. The economic (market) instruments of regulation are analyzed and it is revealed that in European practice such instruments as trade in permits (market instrument) and emission charges (Pig tax) are widely used. Institutional regulatory tools such as disclosure strategies and voluntary initiatives are considered and analyzed. It is substantiated that there is no universal tool that would provide full internalization of negative externalities. It is revealed that in modern conditions, the most successful solution will be the development and improvement 
of tools of direct state regulation of negative externalities in combination with economic (market) instruments, because both economic and market instruments can work effectively and purposefully only if environmental standards are established and observed. environmental quality. The characteristic of application of tools of internalization of negative external effects on an example of slag dumps is given.

Keywords: internalization of negative externalities, tools, European Union, foreign experience, direct instruments of regulation, economic (market) instruments of regulation, tools of institutional regulation, old industrial production models.

Сердюк А. С., Петрова И. П. Обобщение инструментов для интернализации отрицательных внешних эффектов в Европейском Союзе: выводы для Украины

Проведен сравнительный анализ инструментов интернализации отрицательных внешних эффектов. На основе обобщения и оценки возможностей использования инструментов интернализации отрицательных внешних эффектов определены области применения, а также сильные и слабые стороны прямого регулирования, экономических (рыночных) и институциональных инструментов. Охарактеризованы инструменты прямого регулирования, и обнаружено, что они не обеспечивают минимизацию экономических затрат и отличаются высокими затратами административного харак- тера. Проанализированы экономические (рыночные) инструменты регулирования и выявлено, что в европейской практике широко применяются такие инструменты как торговля разрешениями (рыночный инструмент) и плата за выбросы (налог Пигу). Рассмотрены и проанализированы институциональные инструменты регулирования как стратегия раскрытия информации и добровольные инициативы. Обосновано, что не существует универсального инструмента, который обеспечивал бы полную интернализацию негативных внешних эффектов. Выявлено, что в современных условиях, наиболее удачным решением будет развитие и совершенствование инструментов прямого государственного регулирования отрицательных внешних эффектов в сочетании с экономическими (рыночными) инструментами, ведь и экономические, и рыночные инструменты могут эффективно и целенаправленно работать только при условии установления и соблюдения экологических стандартов качества окружающей среды. Охарактеризованы применения инструментов интернализации отрицательных внешних эффектов на примере шлаковых отвалов.

Ключевые слова: интернализация отрицательных внешних эффектов, инструменты, Европейский Союз, зарубежный опыт, прямые инструменты регулирования, экономические (рыночные) инструменты регулирования, инструменты институционального регулирования, старопромышленные модели производства.

Received by the editors: 07.12 .2020 and final form 29.12.2020 